\title{
Curbing Kurdish ethno-nationalism in Turkey: an empirical assessment of pro-Islamic and socio- economic approaches
}

\section{Zeki Sarigil}

To cite this article: Zeki Sarigil (2010) Curbing Kurdish ethno-nationalism in Turkey: an empirical assessment of pro-Islamic and socio-economic approaches, Ethnic and Racial Studies, 33:3, 533-553, DOI: 10.1080/01419870903118114

To link to this article: http://dx.doi.org/10.1080/01419870903118114

曲 Published online: 08 Sep 2009.

Submit your article to this journal $\pi$

Џلll Article views: 819

Q View related articles $\asymp$

4 Citing articles: 13 View citing articles 단 


\title{
Curbing Kurdish ethno-nationalism in Turkey: an empirical assessment of pro- Islamic and socio-economic approaches
}

\author{
Zeki Sarigil \\ (First submission April 2008; First published September 2009)
}

\begin{abstract}
Within the debates on curbing Kurdish ethno-nationalism in Turkey, the pro-Islamic approach puts emphasis on empowering the notion of 'Islamic brotherhood' between Turks and Kurds. The socio-economic approach, on the other hand, draws attention to improving the socio-economic status of the Kurds. By using World Values Survey data, this study tests these two distinct approaches. Logit estimates provide strong support for the socio-economic approach. Individuals with a better socio-economic status (i.e. higher level of education and income) are less likely to support Kurdish ethno-nationalist formations while religion-related factors do not have a significant impact. Some theoretical and policy implications are also provided.
\end{abstract}

Keywords: Ethno-nationalism; Kurds; Islamic brotherhood; income; education; logit.

\section{Introduction}

It is an empirical fact that ethnic and religious tensions constitute the most salient sources of conflict in the contemporary world (Gurr 1993, 2000; Sarkees, Wayman and Singer 2003). The Turkish Republic, too, has been experiencing ethnic and religious challenges (Saatci 2002; Yavuz 2003). It is a widely shared observation that 'identity politics' has been on the rise in Turkey since the early 1980s. Within this process, it is argued, the rise of Islamic, Alevi and Kurdish identities has challenged the organic, monolithic understanding of society (see Bruinessen 1994, 1996; Bozarslan 1996, p. 19; Zubaida 1996; Kirisci and Winrow 1997, p. 121; Onis 1997; Cizre-Sakallioglu 1998; Duran 


\section{Zeki Sarigil}

1998; Yavuz 1999, 2001, p. 11, 2003; Kramer 2000, pp. xiii-11; Ozbudun 2000, p. 143; Somer 2004; Keyman and Icduygu 2005, p. 8; Yavuz and Ozcan 2007).

Although the 'Kurdish question' has been a central issue in both the domestic and foreign policy of the Republic since its initiation in the early 1920s (Watts 1999; Guney 2002, p. 122; AydInli 2002, p. 210; Yavuz and Ozcan 2006, p. 102), Kurdish ethno-nationalism has emerged as one of the biggest challenges to the Turkish state and democracy in the last two or three decades (see Gunter 1997, p. 127; Cizre-Sakallioglu 1998; Kramer 2000, p. 52; Yavuz 1999, 2000, p. 37, 2001; Cornell 2001; Cizre 2002; Moustakis and Chaudhuri 2005, p. 78; Somer 2005, p. 595). ${ }^{1}$ As Yavuz and Ozcan rightly observe:

Today, Turkey is more polarized along ethnic lines than a decade ago, and the Kurdish problem has shifted from the military sphere to the social and political spheres. It is not the Turkish state that is confronting the Kurds any longer but Turks and Kurds confronting each other. (Yavuz and Ozcan 2006, p. 103)

Within such a political environment, the Republic has been struggling to respond to Kurdish demands, which range from the recognition of 'difference' and of cultural and political rights to total separation (Cizre 2002, p. 237; Keyman 2005, p. 268; Yavuz and Ozcan 2006, p. 102).

The central objective of this study is not to provide a discussion of Kurdish ethno-nationalism in Turkey, ${ }^{2}$ but to assess the validity of two different approaches to dealing with the problem: pro-Islamic and socio-economic. The first approach emphasizes strengthening religious attachments and values (i.e. empowering an Islamic brotherhood understanding between Turks and Kurds) in order to curb Kurdish ethno-nationalism, while the second approach draws attention to improving the socio-economic status of individuals, especially in the impoverished south east, populated mostly by the Kurds.

In order to see which one of these approaches or policies might curb Kurdish ethno-nationalism, a better grasp of the factors and dynamics behind pro-Kurdish tendencies in society is needed. However, although there is more open debate and there have been an increasing number of scholarly studies on various aspects of Turkey's Kurdish issue in the last decades (see, for instance, Entessar 1992; McDowall 1996; Olson 1996; Kirisci and Winrow 1997; Barkey and Fuller 1998), the sources of Kurdish ethno-nationalism in society remain relatively under-investigated. Put differently, we have rather limited empirical knowledge of the factors that hinder or accelerate the appeal of Kurdish ethno-nationalist ideas and movements in society. This is rather surprising because a healthy solution to this controversial issue 
requires having a better understanding of the factors and dynamics behind Kurdish ethno-nationalism in the country. The following questions direct this work: Which factors shape Kurdish ethnonationalism in the society? What might be the theoretical and policy-making implications of such an analysis in managing ethnopolitical demands?

By using World Values Survey data, this study investigates the impact of religiosity and socio-economic factors (i.e. the level of income and education) on support for Kurdish ethno-nationalist movements and formations (i.e. Kurdish ethno-nationalism). The statistical results indicate that religiosity does not have a significant impact on the likelihood of Kurdish ethno-nationalism. However, as the level of education and income increases, the likelihood of ethno-nationalist tendencies declines. While supporting the socio-economic approach, these empirical findings disconfirm the pro-Islamic approach. With respect to implications, the findings suggest that, unlike the proIslamic approach, it is difficult to assume a zero-sum relationship between ethnic and religious attachments.

The article proceeds as follows. First, the main theoretical premises of pro-Islamic and socio-economic approaches to Kurdish ethnonationalism are presented along with testable hypotheses. The empirical section then examines those hypotheses through individual-level data provided by the World Values Survey. The conclusion discusses some theoretical and policy implications of the empirical findings.

\section{Theoretical discussion and hypotheses}

\section{Pro-Islamic approach}

This approach anticipates that if individuals identify themselves with Islamic values and understandings, then, the role of ethnicity in selfidentification would decline. This, in turn, should undermine the appeal to Kurdish ethno-political movements and formations. The roots of this approach go back to the Hamidian era (18781908) in the late Ottoman period. The territorial losses in the nineteenth century had made the empire both more Asiatic and Muslim. In order to prevent further losses, Abdulhamit II tried to promote the idea of 'Muslim solidarity' among the different ethnic elements of the empire by emphasizing the caliphate (Bruinessen 1992, p. 268; Zurcher 2003, p. 79).

In the multi-party Republican era, this approach has been expressed several times by various pro-Islamic or conservative parties. For instance, the openly pro-Islamic Refah Partisi (Welfare Party, 1983-98) believed that the destruction of the 'Islamic Brotherhood' by the 
Republican policies of modernization (read Westernization) and secularization, which included the abolition of the caliphate and religious orders and brotherhoods, was one factor which led to the rise of Kurdish ethno-nationalism in the country (see McDowall 1996, p. 439; Yavuz 1998; Duran 1998).

The ruling Adalet ve KalkInma Partisi (Justice and Development Party, AKP), which presents itself as a democratic and conservative centre-right party, also expressed similar views. According to the AKP, the secular nature of the Republic is the main cause of the Kurdish problem in Turkey. As Yavuz and Ozcan (2006, p. 103) suggest, the AKP believed that ' $[t]$ he Kurdish problem is not about nationalism but rather forced secularism and Turkish nationalism of the type enforced by Kemalist ideology. If we stress common Islamic ties and brotherhood, we can enhance the country (memleket) and also end the conflict.' Thus, for the pro-Islamic approach, preventing societal polarization along ethnic lines requires using Islam as cement between Turks and Kurds (see Baslevent, Kirmanoglu and Senatalar 2005, p. 559; Yavuz and Ozcan 2006, p. 103). In other words, it is believed that 'the Islamic layer of identity could be useful in terms of containing ethnic tensions and finding a peaceful solution' (Yavuz 1998, p. 12).

This approach is based on the idea that Islam has traditionally played an important role among the Kurds (see Bruinessen 1992; Yegen 1996, p. 225; Atacan 2001, pp. 111-12; Cizre 2002, pp. 229-30). However, the comprehensive secularization process initiated by the founders of the Turkish Republic in the 1920s loosened this bond between Turks and Kurds and led to the marginalization of the Kurds, who used to identify themselves as part of the Muslim community under Ottoman rule (Entessar 1992, pp. 83-5; Bruinessen 1992, p. 269 , 1994; Yegen 1996, pp. 219-25; Barkey 1998; Yavuz 1998, pp. 11-12; Saatci 2002, p. 557). As Cizre-Sakallioglu (1998, p. 77) notes, proIslamic intellectuals believed that 'by upholding a secular, that is 'antireligious nationalism' based on ethnicity [Turkish], official Turkish nationalism contributed to the rise of its twin sister, Kurdish nationalism'. Thus, it is believed that the Republic's strict secularist policies undermined Islamic values, which once bound different Muslim ethnic groups together, and this in turn empowered Kurdish ethno-nationalism.

The pro-Islamic approach, therefore, asserts that re-emphasizing Islam as a shared value among Turks and Kurds would restrain societal polarization along ethnic lines and consequently curb Kurdish ethno-nationalism (Yavuz 1997, p. 74; Duran 1998). As Houston suggests, 'for Islamist discourse...kardeşlik [Muslim brotherhood] implies the cessation of separatist claims in the name of Muslim unity... and the subordination of Kurdishness to a "higher identity" (üst kimlik)' (1999, p. 91, emphasis in original). For instance, the leader 
of the AKP and the Prime Minister Erdogan once argued that both Turkish and Kurdish identities should be treated as 'ethnic subidentities', which are tied together under a primary identity: 'citizenship' (Hürriyet 25 November 2005; Sabah 23 November 2005; see also Yavuz and Ozcan 2006, pp. 111-12). Within such an understanding of citizenship, Islamic identity is expected to function as a unifying factor among the peoples of Turkey (Yavuz 1998, 17; Gunter and Yavuz 2007, pp. 298; Duran 2008, p. 97). ${ }^{3}$

It was an interesting development that the AKP, which tried to promote the idea of Islamic brotherhood vis-à-vis Kurdish ethnonationalism, received substantial support from Kurdish regions during the November 2002 and July 2007 national elections. It is suggested that the most of AKP's votes in the region came from Islamically influenced Kurdish villages, towns and cities (Yavuz and Ozcan 2006, 109). Gunter and Yavuz, for instance, suggest that:

The AKP is the only party with dense social networks in every corner of the country, along with municipal governments, and all these networks were mobilized for the party's victory. Due to the role of dominant religious networks in the Kurdish regions, the AKP also received a major victory in these provinces. One could conclude that the only chance for ending the relentless and destructive Kurdish insurgency will come from the AKP since it is the only Turkish party that appeals to voters in all Kurdish regions. For the national integration of Turkey, this offers great hope. (Gunter and Yavuz 2007, p. 296, emphasis added)

Thus, inspired by the success of the conservative AKP among the Kurds, conservative circles expected that raising Islamic consciousness to a higher level by empowering religious (Islamic) feelings and attachments should reduce the appeal of Kurdish ethno-nationalism in the region. This discussion leads us to the following hypothetical expectation:

$H_{1}$ : Empowering religious (Islamic) consciousness would reduce the likelihood of appeal to Kurdish ethno-nationalism.

\section{Socio-economic approach}

According to the (relative) deprivation theory, the deprivation of a certain group creates frustration among the members of that group. This in return leads to aggression and hostility vis-à-vis the perceived aggressor(s) and consequently to political mobilization in various forms (Gurr 1970, 1993, p. 167). Gurr states that ' $[\mathrm{g}]$ rievances about differential treatment and the sense of group cultural identity provide 
the essential bases for mobilization and shape the kinds of claims made by the group's leaders' (1993, p. 167). Icduygu, Romano and Sirkeci (1999) support this approach by suggesting that an environment of material and non-material insecurity caused by a low level of socio-economic status and the suppression of group identity might lead to ethnic revival and mobilization. Similarly, Horowitz (1985, pp. 233-9) observes that separatist movements are more likely to be found among backward groups in economically underdeveloped regions.

One implication of this approach is that an increase in the socioeconomic status of the members of the disadvantaged group should restrain ethno-political grievances and demands. Such an understanding is rather strong among the Turkish state and political elite. The official state position on the Kurdish issue is that there is no ethno-political problem in Turkey, but rather a problem of regional terrorism resulting from the socio-economic backwardness of southeastern Turkey (e.g. feudal, tribal social structures, limited economic growth and unemployment in the region) (Kushner 1997, p. 224; Cornell 2001, p. 31; Cizre 2002, p. 248; Lundgren 2007, pp. 67-9).

It is a fact that the region has been the least developed part of the country (for more on regional disparities, see Kirisci and Winrow 1997, pp. 122-6; White 1998; Icduygu, Romano and Sirkeci 1999). It is believed that the socio-economic underdevelopment in the region has led to the alienation of the Kurds from the state and created favourable conditions for separatism or reactionary movements (Entessar 1992, pp. 6-10; McDowall 1996, p. 402). For instance, former Prime Minister Bulent Ecevit (1925-2006) stated to the author that 'Turkey does not have a Kurdish problem. There is a socio-economic underdevelopment in the region. By abusing this, several external actors such as neighbouring and some European countries have promoted Kurdish terrorism/separatism in the region to destabilize and divide the Turkish Republic. ${ }^{4}$

Since it is believed that the socio-economic underdevelopment of the region accelerates reactionary movements against the state and provides 'human material' for the separatist organization PKK, a socio-economic master plan was necessary to reduce the appeal to such formations (Şükrü Elekdag in Aydinli 2002, p. 217; Ismail Cem in Lundgren 2007, p. 45). In brief, the adherents of the view which postulates an inverse relationship between socio-economic status and ethno-nationalism expect that a socio-economic improvement in the south east (e.g. eliminating poverty and feudal structures, increasing education levels) should constrain support for Kurdish ethno-nationalist ideas and movements.

Interestingly, however, one can also argue that, rather than obstructing the 'politics of difference', improvements in the socioeconomic status might actually accelerate it. For instance, Inglehart 
(1977, 1988, pp. 1224-5) observes that the 'high level of prosperity' in post-war Western countries led to the emergence of post-materialist values in those societies. In other words, 'material affluence' in the advanced industrial societies shifted individuals' attention from 'bread and butter issues' to some other concerns such as the sense of community, belonging, self-expression and the quality of life. This might also be expected for ethno-political groups in the sense that a certain degree of the satisfaction of basic material needs (e.g. physical sustenance and safety) of the members of a previously disadvantaged group may pave the way for mobilization of the group members for certain identity-related demands (e.g. cultural and political rights for the group). As several cases across the world indicate, the members of 'advantaged groups' also mobilize for more political rights, such as greater autonomy or total separation (think of the cases of the Catalan and Basque movements in Spain and the Lega Nord in Italy). Considering all these factors, one might hypothesize that:

\section{$H_{2 a}: \quad$ Increases in socio-economic status decrease the likelihood of Kurdish ethno-nationalism. \\ $H_{2 b}$ : Increases in socio-economic status increase the likelihood of Kurdish ethno-nationalism.}

Before moving further, it is important to indicate at this point that these two approaches might be distinct but they may also coexist. For instance, although AKP officials express pro-Islamic views on the Kurdish issue, they also believe that some other factors such as limited socio-economic development in the region have also contributed to this problem. For instance, during his Diyarbakir visit (12 August 2005), conservative PM Erdogan openly stated that 'Turkey has a Kurdish problem. In the past, Turkish Republic made some mistakes in dealing with this problem. However, the solution should be more democracy, more citizenship rights and more welfare' (Radikal 13 August 2005) Thus, although it is analytically useful to treat proIslamic and socio-economic approaches as distinct understandings, a combination of these two is also a possibility in the real world. In other words, it is difficult to treat them as mutually exclusive approaches.

Furthermore, the reverse is also a possibility in the sense that even secular circles sometimes toy with the idea of promoting religion as an antidote against Kurdish ethno-nationalism. For instance, the strictly secular Turkish military once distributed in Kurdish areas pamphlets containing verses of the Koran which hailed obedience to state authority (Oran 2001; see also McDowall 1996, p. 432). This is a clear indication that a pro-Islamic approach is not necessarily defended exclusively by religiously conservative circles. The following 
section empirically tests to what extent these two approaches might be useful in curbing Kurdish ethno-nationalism in Turkey.

\section{Research design and method}

Ethno-nationalism is defined as the "transformation of ethnicity from a purely personal quest for meaning and belonging into a group demand for respect and power' (Rothschild 1981, p. 6). It should be acknowledged that it is a rather challenging task to come up with a direct measurement of the notion of ethno-nationalism. However, this study utilizes a proxy for having a sense of Kurdish ethno-nationalism in society: support for ethno-political formations. It simply refers to voting for Kurdish ethno-nationalist or ethno-political formations and movements (e.g. an ethnic party), which seek to 'combat ethnic antagonists or to impress ethnically defined interests [e.g. cultural, political rights] on the agenda of the state' (Esman, quoted in Watts 2006, p. 132).

In the 1990s, several pro-Kurdish parties emerged on the Turkish political stage, such as the People's Labour Party [HEP] 1990-3, the Democracy Party [DEP] 1993-4 and the People's Democracy Party [HADEP] 1994-2003. These parties represented a kind of 'issue parties' because their primary concern was the Kurdish problem. In general, they argued that the Kurdish problem could not be reduced to a security problem. Rather, it was primarily an ethno-political matter. Therefore, they claimed, there was an urgent need for a political solution such as the granting of autonomy or cultural rights to the Kurds (e.g. publishing, broadcasting and teaching in Kurdish), halting the state of emergency in the south-eastern Turkey and an amnesty for PKK members (see Barkey 1998; Guney 2002; Watts 1999, 2006). They have also advocated socio-economic development in the south east, where the Kurds constitute the vast majority of the population. ${ }^{5}$

In operationalizing the notion of 'Kurdish ethno-nationalism', this study uses support for the pro-Kurdish HADEP, the party operating at the time of the survey. Like its predecessors, HADEP also viewed the Kurdish issue as an ethno-political issue and as one of the most important political problems of the Republic. Thus, as a typical proKurdish party, HADEP was a good representation of an ethnopolitical movement (also see Yavuz 1999). ${ }^{6}$ Therefore support for this party should give us some sense of Kurdish ethno-nationalism.

The independent variables of interest are religiosity, income and education. Religiosity here refers to the significance of religion in one's life. In measuring this concept, individuals' responses to the question of 'how important is religion in your life?' are used. However, in order to minimize measurement error, alternative indicators such as 'attending religious services' (i.e. the frequency of visiting mosque) and 'self-identification as a religious person' are also used in 
operationalizing this key variable. ${ }^{7}$ With respect to measuring the socio-economic status of individuals, income (household) and education levels are used (see Appendix A).

\section{Control variables}

I also control for a number of factors that might shape individuals' attitudes vis-à-vis ethno-nationalist movements. For instance, (Turkish) nationalists should be less likely to support Kurdish ethno-nationalist movements and groups. Ideology (left vs. right) might also play some role because it is a fact that pro-Kurdish movements and parties have been characterized by leftist discourses (Barkey 1998; Guney 2002, p. 127). Thus, left-oriented individuals should be more supportive of Kurdish ethno-political actors. Another factor that we should take into account is regional identification. It is argued that the regional concentration of ethnic groups might facilitate group mobilization by providing shared grievances. These shared resentments might increase support for ethno-nationalist formations in such regions (see Gurr 1993, p. 175; Gurr and Harff 1994; also Watts 2006, p. 130). It is actually the case that, compared to western Turkey, individuals in the primarily Kurdish south-eastern provinces are more likely to vote for proKurdish candidates (Watts 2006, p. 130; Yavuz 1999, p. 134). Thus, one might expect that individuals with strong regional attachments might find ethno-nationalist movements more appealing than individuals having attachments to, say, the whole country. Gender and age, standard factors in public opinion analyses, are also included in the model as possible predictors of pro-Kurdish attitudes (see Appendix A for the measurement of all variables). ${ }^{8}$

\section{Data, sample and estimation technique}

In order to test hypotheses presented above, this study uses data provided by the World Values Survey (1999-2000). ${ }^{9}$ The original sample included more than 4500 respondents from various parts of the country. However, due to missing values, the sample used in this study includes 2967 respondents. To facilitate interpretation, certain recoding was also made to the data set (see Appendix A). The dependent variable measures 'support for an ethno-political formation (i.e. HADEP)'. Since it is binary (0: none; 1: pro), using the popular OLS (ordinary least squares) estimates would not be appropriate because OLS estimates with a discrete dependent variable are likely to violate the assumption of homoscedasticity (constant variance of the error term across the sample) and of a normally distributed error term 
(Long 1997). Therefore this study uses logistic regression as a statistical method.

\section{Statistical results}

Table 1 presents logit estimates. The statistical results reveal the rather interesting situation that, although there is a negative relationship between religiosity and the likelihood of Kurdish ethno-nationalism, it is not statistically significant. I used different measurements of the notion of 'religiosity' but the results were the same, which suggest that increases in the level of religiosity do not really reduce the likelihood of support for ethno-political formations. This finding implies that ethnic awareness is not necessarily incompatible with religious consciousness in the sense that Kurdish ethnic identity may coexist with Islamic identity. In other words, unlike the pro-Islamic approach, which assumes a zero-sum relationship between these two factors, increased religiousness is not antithetical to Kurdish nationalism. As Atacan's (2001) analysis of Med-Zehra, a Kurdish Islamic movement in Turkey, also shows us, there may also be Kurdish ethno-nationalists who are heavily influenced by Islamic ideas and values. Therefore, the proIslamic approach should not ignore the possibility of ethno-religious sentiments among the Kurds.

Table 1. Logit analysis of 'Kurdish ethno-nationalism'

\begin{tabular}{lc}
\hline Predictors & $\begin{array}{c}\text { Estimates } \\
\text { Dep. var.: Kurdish ethno-nationalism }\end{array}$ \\
\hline Religiosity & $-.0093725(.1439323)$ \\
Income & $-.2772304^{* *}(.1031143)$ \\
Education & $-.1667951^{*}(.0718978)$ \\
Control variables & \\
Nationalist & $-1.130441^{* * *}(.120256)$ \\
Ideology (left-right) & $-.3611055^{* * *}(.0662517)$ \\
Regional attachments & $-.2031714^{*}(.0931735)$ \\
Gender & $.2871644(.2724574)$ \\
Age & $-.0063614(.0094577)$ \\
$\mathrm{N}$ & 2967 \\
Pseudo $\mathrm{R}^{2}$ & 0.3096 \\
Log likelihood & -258.9703 \\
Wald chi2(8) & 233.69 \\
Prob $>$ chi2 & 0.0000 \\
\hline
\end{tabular}

Notes

${ }^{*} p<.05,{ }^{* *} p<.01,{ }^{* * *} p<.001$.

Robust standard errors are in parentheses. 
However we should note that there are sharp differences between Kurdish Islamists' and pro-Islamists' approaches to religion. As Houston rightly observes, the understanding of 'Muslim brotherhood', which is considered as a key to solving the Kurdish problem by proIslamists, is regarded as 'an acknowledgement of their created cultural particularity' by Kurdish Islamists. Houston (1999, p. 91) suggests that, for Kurdish Islamists, şeriat (Islamic law) represents a refuge, which provides them a legal space to express their Kurdishness (see also Bruinessen 2000, p. 15). In her analyses of Islamist writers, Sakallioglu also draws attention to this difference:

Kurdish-Islamist writers tend to search for a 'space' for Kurdish ethnic distinctiveness within the framework of the suggested formula of ummah, the Islamic community of the faithful, while the position of the Turkish-Islamist writers leans heavily toward defending the integrity of the Turkish state rather than to acknowledging a Kurdish ethnic distinctiveness. (Cizre-Sakallioglu 1998, p. 75)

Thus, religion in Kurdish Islam does not necessarily obstruct ethnic awareness, which is also supported by the empirical findings of this study. This finding is also consistent with the observation that the revival of Islam in Turkey in the last two or three decades had limited influence on Kurdish nationalism. Therefore, given the fact that religiosity does not really reduce the likelihood of ethno-nationalist tendencies, the promotion of the idea of 'Islamic brotherhood' as an antidote against Kurdish ethno-nationalism becomes an unsound project.

However, this empirical finding raises a further question that we need to address: how can we explain the substantial Kurdish support for certain pro-Islamic or conservative parties which advocate transcending ethnic particularisms and demands? Given the fact that pro-Islamic parties in general put emphasis on the notion of the broader Islamic community (ümmet) and Islam as a binding factor between Turks and Kurds and reject ethno-nationalist understandings and demands (Atacan 2001, p. 111), it becomes puzzling that they still perform relatively well among the Kurds (see also Baslevent, Kirmanoglu and Senatalar 2005, p. 559; Bozarslan 1996, p. 18; Duran 1998; Atacan 2001, p. 111). What factors might account for this perplexing situation?

As an explanation for the success of the explicitly pro-Islamic Welfare Party among the Kurds, for instance, Bozarslan (1996, p. 18) suggests that ideological and reactionary motivations were primary factors behind this political outcome. Similarly, Yavuz (1998, pp. 11$13,1999,2003)$ suggests that the 'oppositional identity' of the proIslamic parties has appealed to the Kurds, who were also marginalized 
by the political system. With respect to the success of the AKP, for instance, Gunter and Yavuz (2007, p. 297) state that '[m]any Kurds regard the AKP as an anti-Kemalist and anti-systemic party that has been "suppressed" by the same enemy as they have'. Thus, it is believed that such a perception promoted the popularity of these parties among the Kurds.

This argument, however, is problematic for the following reason. If we follow the logic that the Kurds tend to support political parties with 'oppositional identity', then the explicitly pro-Islamic Saadet Partisi (Felicity Party), which represents much stronger oppositional and revisionist identities, should have received more votes in the region than the AKP during the last national elections (July 2007). It is a fact that, compared to the explicitly revisionist and pro-Islamic SP, the AKP appears to be more pro-Western, moderate, centrist and conciliatory vis-à-vis the state establishment (see Mecham 2004; Nasr 2005, p. 23; Gunter and Yavuz 2007, pp. 292-3). However, the AKP performed much better among the Kurds than the unabashedly proIslamic SP. ${ }^{10}$ Thus, it is difficult to argue that the popularity of certain pro-Islamic or conservative parties among Kurdish ethno-nationalists is due to their Islamist ideology or oppositional identity. Therefore, there must be other factors that could account for this perplexing situation.

My hunch is that the popularity of certain pro-Islamic or conservative parties among the Kurds (e.g. the RP and the AKP) might be due to their relatively better performances in managing the economy, thereby bringing a certain degree of stability to the country and, more importantly, providing certain material benefits to impoverished Kurdish people in shanty towns (both in the western and eastern parts of the country) such as providing them with shelter, jobs, food and fuel, and developing certain clientelistic relationships such as attending weddings, circumcisions and burial ceremonies (see Onis 1997; Barkey 1998; see also White 2002; Toprak 2005, p. 181; Yavuz and Ozcan 2007, pp. 130-1). We should bear in mind that one characteristic of the Turkish party system has been the high degree of volatility, which refers to 'sudden and significant changes in party votes from one election to the next' (Ozbudun 2000, pp. 74-80). This political reality seems to suggest that ideological concerns/attachments do not play a substantial role in voting preferences among Turkish electorate. Within such a political culture, clientelistic relations and material benefit concerns might play a greater role in shaping voters' preferences. As a result, we can expect that political patronage has been playing a similar role in Kurdish support for the pro-Islamic parties in Turkey.

Another interesting finding is that there is a negative and statistically significant relationship between socio-economic factors 
(income and education levels) and support for ethno-nationalist formations. Put differently, individuals with a better socio-economic status (i.e. higher level of education and income) are less likely to have ethno-nationalist tendencies. This finding negates the arguments that are sceptical of a negative relationship between socio-economic status and ethno-political demands. For instance, Aydinli suggests that:

Of course, there are challenges to an economic understanding and to economic endeavours. First, it is far from proven theoretically that economic developments will silence the political/cultural demands of the emerging Kurdish politics. The unreliability of an economic solution is even greater in the wake of such a long and confrontational experience, which may very well have increased ethnic and political awareness among the Kurds. (Aydinli 2002, p. 218)

As discussed above, theoretically there are competing orientations within the socio-economic approach. However, the statistical results of this study support the position that anticipates that an improvement in the socio-economic status of disadvantaged individuals is likely to constrain support for ethno-political formations. At least, this is what we see in the Turkish context. This finding is also consistent with the postulation given above that the popularity of pro-Islamic parties among the Kurds might be due to their relatively better performances in delivering certain material benefits to these needy people.

That said, this finding may not disconfirm the hypothesis which claims a positive relationship between these two factors. It might be the case that there may be a certain threshold after which socioeconomic development accelerates ethno-political awareness, paving the way for identity-related mobilization and demands. In other words, there might be a curvilinear relationship between socio-economic status and ethno-nationalist attitudes. In order to see whether this is the case, we need to design comparative studies and look at how these two factors interrelate in other socio-political contexts.

With respect to the control variables, as expected, (Turkish) nationalists are less likely to be supportive of Kurdish ethnonationalism. Similarly, moving from the left to the right of the political spectrum decreases the likelihood of Kurdish ethnonationalism. However, it is striking that individuals, who have strong regional attachments, are more likely to have ethno-nationalist tendencies. In other words, an individual, who identifies herself with her region or province rather than with the country, is more likely to have a pro-Kurdish tendency. However gender and age did not matter. 
The following final section discusses some implications of these empirical findings.

\section{Implications}

This study investigated the impact of religiosity and socio-economic factors on the appeal to Kurdish ethno-nationalist movements and formations in order to have a better assessment of two distinct approaches (i.e. pro-Islamic and socio-economic) shaping efforts to deal with Kurdish ethno-nationalism in Turkey. Statistical results indicate that religiosity does not really matter in terms of the likelihood of Kurdish ethno-nationalism. In other words, increases in religiosity do not necessarily reduce ethnic awareness. Interestingly, however, as the level of education and income increases, the likelihood of Kurdish ethno-nationalism decreases. These findings raise doubts about the validity of the pro-Islamic approach but they do provide some support for the socio-economic approach in constraining Kurdish ethno-nationalism.

If we move from research findings to policy recommendations, it would be difficult to suggest that socio-economic development alone would be the panacea for Turkey's Kurdish problem, a rather complicated issue involving political, trans-national and security dimensions. However, the empirical findings of this study clearly suggest that socio-economic development in the impoverished Kurdish regions would certainly make the problem more manageable. That said, a caveat is in order: in the long run, socio-economic development might accelerate ethno-political awareness and demands. As indicated above, the 'politics of difference' can also be strong among the members of advantaged groups. Therefore, socio-economic policies should be accompanied by other measures such as granting certain cultural rights.

To be fair, since the Turkish Republic was recognized as a candidate state for European Union [EU] membership in 1999, Turkey has achieved significant constitutional, legislative and institutional changes in the post-Helsinki era, which brought Turkey much closer to the EU standards in terms of the level of human rights. Within this process, Turkish governments have granted certain cultural rights (e.g. allowing broadcasting in Kurdish and learning Kurdish through private language courses) for the Kurds on the basis of individual rights. However, the author's interviews with certain pro-Kurdish leaders and activists indicate that although these changes are regarded as important, they fall short of being satisfactory. ${ }^{11}$

The state establishment tends to reduce the Kurdish issue to a matter of security (i.e. terrorism) and regional underdevelopment, ignoring its ethno-political dimensions due to fears that responding to 
identity-related demands might result in separation (Yegen 1996, p. 216). Such an understanding, however, does not remove the Kurdishness of the Kurdish question. Therefore, the Turkish Republic should be much more responsive to the demands of Kurdish identity. Other than socio-economic measures, such measures should be another tool to be used in dealing with Kurdish ethno-nationalism. This, in turn, would also promote the consolidation of liberal democracy in EU-hopeful Turkey.

\section{Postscript}

In March 2009, Turkey held local elections. The election results provide further empirical evidence for the arguments of this study. It is striking that the popularity of the ruling, conservative AKP in provinces populated mostly by the Kurds decreased from 45 per cent to 31.5 per cent, while the pro-Kurdish DTP increased its votes in those places to 44 per cent and regained the control of several municipalities. This result was shocking for the AKP officials and conservative circles because it was expected that certain initiatives by the conservative government such as the introduction of a public TV channel, which broadcasts only in Kurdish (TRT 6), would promote Kurdish support for the religion-sensitive party. Despite this, the Kurds opted for voting for the openly ethnonationalist party. This outcome clearly indicates that neither the AKP's conservative identity nor the idea of 'Islamic brotherhood' promoted by conservative circles necessarily constrains or weakens ethno-nationalist tendencies among the Kurds.

\section{Acknowledgements}

I would like to thank Martin Van Bruinessen, Umit Cizre, Cenap Cakmak, Jay Fisher, Michael Gunter, Metin Heper, Hasan Kirmanoglu, Robert Olson, Michael Wuthrich, Hakan Yavuz, the reviewers and editors for their very helpful comments and suggestions on earlier versions of this article.

\section{Notes}

1. In the early 1980s, an armed conflict erupted between the security forces and the separatist PKK (Kurdistan Workers Party, Partiya Karkaren Kurdistan, established in 1978). The number of people killed between 1984 and 1999 is estimated to have been around 30,000 (half of them PKK members, one-quarter civilians and one-quarter security members). The cost of fighting, during this period, was more than 100 billion dollars. Although its intensity has declined dramatically since the capture of PKK leader Ocalan by Turkish security forces in 1999 in Kenya, the fighting resumed in the spring of 2005. 


\section{Zeki Sarigil}

2. For more on the evolution and impact of Kurdish ethno-nationalism in Turkey, see Entessar (1992), McDowall (1996) and Olson (1996).

3. It is important to indicate that this approach was rather different from the official state position, which treats Kurdish, Bosniak, Albanian and Chechen identities as sub-identities under the Turkish identity (Yavuz and Ozcan 2006, p. 112). In the following period, the Turkish military expressed its concerns about such an initiative. The military argued that the treatment of the Turkish identity as an ethnic sub-identity was contradictory to the unitary nature of the Turkish nation-state.

4. Author's interview, Oran-Ankara, 25 December 2005.

5. It is argued that Kurds constitute 70 per cent of the population in the eastern and south-eastern parts (see Mutlu 1996).

6. The party participated in the 1995 and 1999 national elections. Although it could not pass the nationwide election threshold (10 per cent), the party received the majority of votes in the south east, populated mostly by Kurds (Bozarslan 1996, p. 18; Kurkcu 1996, p. 4). Moreover, in 1999 municipal elections, HADEP's candidates won most of major cities and towns in the region (Barkey 1998; Guney 2002).

7. For a similar measurement of 'religiosity', see Baslevent, Kirmanoglu and Senatalar (2005, p. 554).

8. One might argue that we should also control for 'ethnic origin' because it might well be expected that ethnic Kurds should be more likely to be supportive of pro-Kurdish formations. However, it is a fact that not all pro-Kurdish actors are ethnic Kurds and not all Kurds are pro-Kurdish (Watts 2006, p. 132). Therefore, the exclusion of ethnic origin does not pose a major problem in terms of model specification.

9. The World Values Survey data set is produced by the European Values Study Foundation and World Values Survey Association. The goal of the project is to learn more about values and cultural changes in societies all over the world. It is a highly used data set in scholarly analyses of public attitudes and values. The data source is: European and World Values Surveys Four-Wave Integrated Date File, 1981-2004, v.20060423, 2006 (Turkey, November-December 2000). For more information, see http://www.worldvaluessurvey.org/ The survey data for Turkey were collected by Bogazici University in November-December 2000.

10. During the July 2007 national elections, the AKP received 45 per cent of total votes in provinces mostly populated by Kurds (Diyarbakir, Van, Siirt, Sanliurfa, Mus, Mardin, Hakkari, Sirnak, Batman, Bitlis). The pro-Kurdish DTP, however, received 40 per cent of the votes in those places. The openly pro-Islamic SP performed rather poorly.

11. Author's interviews with: Ahmet Turk (co-leader of the pro-Kurdish Democratic Society Party, DTP); Edip Polat (the Chairperson of Kurdish Writers Association); Mustafa Sezgin Tanrikulu (the President of the Bar of Diyarbakir); Osman Baydemir (Diyarbakir Mayor); Selahattin Demirtas (the Chairperson of Human Rights Association, Diyarbakir Branch); Servet Deniz (Kurdish Institute); Songul Erol Abdil (Tunceli Mayor); Yusuf Alatas (the President of Human Rights Association) in Ankara, Tunceli and Diyarbakir, in JuneJuly 2006.

\section{References}

ATACAN, FULYA 2001 'A Kurdish Islamist Group in modern Turkey: shifting identities', Middle Eastern Studies, vol. 37, no. 3, pp. 111-44

AYDINLI, ERSEL 2002 'Between security and liberalization: decoding Turkey's struggle with the PKK', Security Dialogue, vol. 33, no. 2, pp. 209-25

BARKEY, HENRY J. 1998 'The People's Democracy Party (HADEP): the travails of a legal Kurdish party in Turkey', Journal of Muslim Minority Affairs, vol. 18, no. 1, pp. 129-38 BARKEY, HENRY J. and FULLER, GRAHAM E. 1998 Turkey's Kurdish Question, Lanham, MD: Rowman \& Littlefield 
BASLEVENT, CEM, KIRMANOGLU, HASAN and SENATALAR, BURHAN 2005 'Empirical investigation of party preferences and economic voting in Turkey', European Journal of Political Research, vol. 44, pp. 457-562

BOZARSLAN, HAMIT 1996 'Turkey's elections and the Kurds', Middle East Report (Turkey: Insolvent Ideologies, Fractured State), vol. 199, pp. 16-19

BRUINESSEN, MARTIN VAN 1992 Agha, Shaikh and State: The Social and Political Structures of Kurdistan, London and Atlantic Highlands, NJ: Zed Books

1994 'Nationalisme kurde et ethnicités intra-kurdes' (Kurdish nationalism and competing ethnic loyalties), Peuples Méditerranéens, vol. 68-9, pp. 11-37

1996 'Kurds, Turks and Alevi revival in Turkey', Middle East Report (Minorities in the Middle East: Power and the Politics of Difference), vol. 200, pp. 7-10

2000 Mullas, Sufis and Heretics: The Role of Religion in Kurdish Society (Collected Articles), Istanbul: The Isis Press

CIZRE, UMIT 2002 'Turkey's kurdish problem: a critical analysis of boundaries, Identity and hegemony', in Brendan O'Leary, Ian S. Lustick and Thomas Callaghy (eds), Rightsizing the State: The Politics of Moving Borders, New York: Oxford University Press, pp. 222-52 CIZRE-SAKALLIOGLU, UMIT 1998 'Kurdish nationalism from an Islamist perspective: the discourse of Turkish Islamist writers', Journal of Muslim Minority Affairs, vol. 18, no. 1, pp. $73-90$

CORNELL, SVANTE E. 2001 'The Kurdish question in Turkish politics', Orbis, vol. 45, no. 1, pp. $31-46$

DURAN, BURHANETTIN 1998 'Approaching the Kurdish question via "Adil Düzen": an Islamist formula of the Welfare Party for Ethnic Coexistence', Journal of Muslim Minority Affairs, vol. 18, no. 1, pp. 111-29

2008 'The Justice and Development Party's 'new politics': steering toward conservative democracy, a revised Islamic agenda or management of new crises?' in Umit Cizre (ed.), Secular and Islamic Politics in Turkey: The Making of the Justice and Development Party, London and New York: Routledge, pp. 80-107

ENTESSAR, NADER 1992 Kurdish Ethnonationalism, Boulder, CO, and London: Lynne Rienner

GUNEY, AYLIN 2002 'The People's Democracy Party', Turkish Studies, vol. 3, no. 1, pp. $122-37$

GUNTER, MICHAEL M. 1997 The Kurds and the Future of Turkey, New York: St. Martin's Press

GUNTER, MICHAEL M. and YAVUZ, HAKAN M. 2007 'Turkish paradox: progressive Islamists versus reactionary secularists', Critique: Critical Middle Eastern Studies, vol. 16, pp. 289-301

GURR, TED R. 1970 Why Men Rebel, Princeton, NJ: Princeton University Press 1993 'Why minorities rebel: a global analysis of communal mobilization and conflict since 1945', International Political Science Review, vol. 14, no. 2, pp. 161-201

2000 Peoples vs. States: Minorities at Risk in the new Century, Washington, DC:

United States Institute of Peace

GURR, TED ROBERT and HARFF, BARBARA 1994 Ethnic Conflict in World Politics, Boulder, CO: Westview

HOROWITZ, DONALD L. 1985 Ethnic Groups in Conflict, Berkeley and Los Angeles, CA: University of California Press

HOUSTON, CHRISTOPHER 1999 'Civilizing Islam, Islamist civilizing? Turkey's Islamist movements and the problem of ethnic difference', Thesis Eleven, vol. 58, pp. 83-98

ICDUYGU, AHMET, ROMANO, DAVID and SIRKECI, IBRAHIM 1999 'The ethnic question in an environment of insecurity: the Kurds in Turkey', Ethnic and Racial Studies, vol. 22, no. 6, pp. 991-1010

INGLEHART, RONALD 1977 The Silent Revolution: Changing Values and Political Styles among Western Publics, Princeton, NJ: Princeton University Press 
1988 'The renaissance of political culture', The American Political Science Review, vol. 82, no. 4, pp. $1203-30$

KEYMAN, E. FUAT 2005 'Articulating citizenship and identity: the "Kurdish question" in Turkey', in E. Fuat Keyman and Ahmet Icduygu (eds), Citizenship in a Global World: European Questions and Turkish Experiences, London and New York: Routledge, pp. 267-88 KEYMAN, E. FUAT and ICDUYGU, AHMET 2005 'Introduction: citizenship, identity and the question of democracy in Turkey' in E. Fuat Keyman and Ahmet Icduygu (eds), Citizenship in a Global World: European Questions and Turkish Experiences, London and New York: Routledge, pp. 1-27

KIRISCI, KEMAL and WINROW, GARETH M. 1997 The Kurdish Question and Turkey: An Example of Trans-state Ethic Conflict, London: Frank Cass

KRAMER, HEINZ 2000 A Changing Turkey: The Challenge to Europe and the United States, Washington, DC: Brookings Institution Press

KURKCU, ERTUGRUL 1996 'The crises of the Turkish state', Middle East Report, vol. 199 pp. $2-7$

KUSHNER, DAVID 1997 'Self-perception and identity in contemporary Turkey', Journal of Contemporary History, vol. 32, no. 2, pp. 219-33

LONG, J. SCOTT 1997 Regression Models for Categorical and Limited Dependent Variables, Thousand Oaks, CA: Sage

LUNDGREN, ASA 2007 The Unwelcome Neighbor: Turkey's Kurdish Policy, London and New York: I. B. Tauris

MCDOWALL, DAVID 1996 A Modern History of the Kurds, London: I. B. Tauris

MECHAM, R. QUINN 2004 'From the ashes of virtue, a promise of light: the transformation of political Islam in Turkey', Third World Quarterly, vol. 25, no. 2, pp. $339-58$

MOUSTAKIS, FOTIOS and CHAUDHURI, RUDRA 2005 'Turkish-Kurdish relations and the European Union: an unprecedented shift in the Kemalist paradigm', Mediterranean Quarterly, vol. 16, no. 4, pp. 77-89

MUTLU, SERVET 1996 'Ethnic Kurds in Turkey: a demographic study', International Journal of Middle East Studies, vol. 28, no. 4, pp. 517-41

NASR, VALI 2005 'The rise of Muslim democracy', Journal of Democracy, vol. 16, no. 2, pp. 13-27

OLSON, ROBERT (ed.) 1996 The Kurdish Nationalist Movement in the 1990s: Its Impact on Turkey and The Middle East, Lexington, KY: University of Kentucky Press

ONIS, ZIYA 1997 'The political economy of Islamic resurgence in Turkey: the rise of the Welfare Party in perspective', Third World Quarterly, vol. 18, no. 4, pp. 743-66

ORAN, BASKIN 2001 'Kemalism, Islamism and globalization: a study on the focus of supreme loyalty in globalizing Turkey', Southeast European and Black Sea Studies, vol. 1, no. 3 , pp. $20-50$

OZBUDUN, ERGUN 2000 Contemporary Turkish Politics: Challenges to Democratic Consolidation, Boulder, $\mathrm{CO}$, and London: Lynne Rienner

ROTHSCHILD, JOSEPH 1981 Ethnopolitics: A Conceptual Framework, New York: Columbia University Press

SAATCI, MUSTAFA 2002 'Nation-states and ethnic boundaries: modern Turkish identity and Turkish-Kurdish conflict', Nations and Nationalism, vol. 8, no. 4, pp. 549-64

SARKEES, MEREDITH R., WAYMAN, FRANK W. and SINGER, J. DAVID 2003 'Inter-state, intra-state and extra state wars: a comprehensive look at their distribution over time 1816-1997', International Studies Quarterly, vol. 47, no. 1, pp. 49-70

SOMER, MURAT 2004 'Turkey's Kurdish conflict: changing context, and domestic and regional implications', The Middle East Journal, vol. 58, no. 2, pp. 235-53

2005 'Resurgence and remaking of identity: civil beliefs, domestic and external dynamics, and the Turkish mainstream discourse on Kurds', Comparative Political Studies, vol. 38 , no. 6 , pp. $591-622$ 
TOPRAK, BINNAZ 2005 'Islam and democracy in Turkey', Turkish Studies, vol. 6, no. 2, pp. $167-86$

WATTS, NICOLE F. 1999 'Allies and enemies: pro-Kurdish parties in Turkish politics', International Journal of Middle East Studies, vol. 31, no. 4, pp. 631-56

2006 'Activists in office: pro-Kurdish contentious politics in Turkey', Ethopolitics, vol. 5 , no. 2 , pp. $125-44$

WHITE, JENNY B. 2002 Islamist Mobilization in Turkey: A Study in Vernacular Politics, Seattle, WA, and London: University of Washington Press

WHITE, PAUL J. 1998 'Economic marginalization of Turkey's Kurds: the failed promise of modernization and reform', Journal of Muslim Minority Affairs, vol. 18, no. 1, pp. 139-58

YAVUZ, M. HAKAN 1997 'Political Islam and the Welfare (Refah) Party in Turkey', Comparative Politics, vol. 30, no. 1, pp. 63-82

1998 'A preamble to the Kurdish question: the politics of Kurdish identity', Journal of Muslim Minority Affairs, vol. 18, no. 1, pp. 9-18

1999 'Search for a new social contract in Turkey: Fethullah Gulen, the Virtue Party and the Kurds', SAIS Review, vol. 19, no. 1, pp. 114-43

2000 'Turkey's fault lines and the crisis of Kemalism', Current History, vol. 99, no. 633 , pp. $33-8$

2001 'Five stages of the construction of Kurdish nationalism in Turkey', Nationalism and Ethnic Politics, vol. 7, no. 3, pp. 1-24

2003 Islamic Political Identity in Turkey, London: Oxford University Press

YAVUZ, M. HAKAN and OZCAN, NIHAT ALI 2006 'The Kurdish question and Turkey's Justice and Development Party', Middle East Policy, vol. 13, no. 1, pp. 102-19

2007 'Crisis in Turkey: the conflict of political languages', Middle East Policy, vol. 14, no. 3, pp. $118-35$

YEGEN, MESUT 1996 'The Turkish state discourse and the exclusion of Kurdish identity', Middle Eastern Studies, vol. 32, no. 2, pp. 216-29

ZUBAIDA, SAMI 1996 'Turkish Islam and national identity', Middle East Report, vol. 199, pp. $10-15$

ZURCHER, ERIK J. 2003 Turkey: A Modern History, London and New York: I. B. Tauris

ZEKI SARIGIL is Assistant Professor in the Department of Political Science at Bilkent University.

ADDRESS: Department of Political Science, Bilkent University, 06800 Bilkent, Ankara, Turkey. Email: sarigil@bilkent.edu.tr 
Appendix A. Variables and measurement

Survey question used for measurement

\begin{tabular}{llll}
\cline { 2 - 3 } Variable & & Original & Recoded \\
\hline Kurdish & V183 (v220): If there were a national election tomorrow, for which party on & \\
ethno-nationalism & $\begin{array}{l}\text { this list would you vote? } \\
\text { 1. ANAP }\end{array}$ & 6. HADEP & 1. HADEP \\
& 2. CHP & 7. MHP & Other \\
3. DSP & 8. Other & 10. None \\
4. DYP & &
\end{tabular}

Religiosity V9 (v9): How important is religion in your life?

1. Very important

0 . Not at all important

2. Rather important

3. Not very important

1. Not very important

4. Not at all important

2. Rather important

3. Very important

Income

S198 (v236): Here is a scale of incomes. We would like to know in what group your household is, counting all wages, salaries, pensions and other incomes that come in?

(Low) $1234 \ldots \ldots \ldots \ldots \ldots . \ldots 10$ (High)

Education $\quad$ V189 (v226): What is the highest educational level that you have attained?

1. No formal education

2. Incomplete primary school

9. University-level education, with degree

Nationalist

V180 (v216): How proud are you to be Turkish? 
Appendix A (Continued)

Survey question used for measurement

\begin{tabular}{|c|c|c|}
\hline Variable & Original & Recoded \\
\hline & $\begin{array}{l}\text { 1. Very proud } \\
\text { 2. Quite proud } \\
\text { 3. Not very proud } \\
\text { 4. Not at all proud }\end{array}$ & $\begin{array}{l}\text { D. Not at all proud } \\
\text { 1. Not very proud } \\
\text { 2. Quite proud } \\
\text { 3. Very proud }\end{array}$ \\
\hline Ideology (left-right) & $\begin{array}{l}\text { V106 (v139): In political matters, people talk of 'the left' and 'the right'. How would you } \\
\text { place your views on this scale, generally speaking? } \\
1 \text { (left) } \ldots \ldots \ldots \ldots \ldots \ldots \ldots \text { (right) }\end{array}$ & \\
\hline Regional identification & $\begin{array}{l}\text { V178 (v214): Geographical identification } \\
\text { 1. Local } \\
\text { 2. Region } \\
\text { 3. Country } \\
\text { 4. Continent } \\
\text { 5. The world }\end{array}$ & \\
\hline Gender & $\begin{array}{l}\text { V186 (v223): Sex of respondent } \\
\text { 1. Male } \\
\text { 2. Female }\end{array}$ & $\begin{array}{l}\text { 0. Female } \\
\text { 1. Male }\end{array}$ \\
\hline Age & V188 (v225): Age of the respondent (18-91) & \\
\hline
\end{tabular}

